\title{
Quality Characteristics Carcasses Of New Zealand White Crossbred Rabbit Was Given FOS (Fructooligosaccharide) From Ambon Banana Peel Isolation
}

\author{
SK Syahpura ${ }^{1^{*}}$, Zulfahmi $^{2}$ and A Sofiana ${ }^{1}$ \\ ${ }^{1}$ Department of Animal Husbandry of Politeknik Negeri Lampung, Indonesia \\ ${ }^{2}$ Department of Technology Agriculture of Politeknik Negeri Lampung, Indonesia
}

*Corresponding author: ivisoraya@polinela.ac.id

\begin{abstract}
Fructooligosaccharide (FOS) is an alternative solution to control colibacillosis which can eliminate pathogenic bacteria in the contamination tract and stimulate the immune system (immunostimulants). The fructan contained in FOS produced by hydrolysis of chicory plant inulin has been widely reported, but the production of FOS from banana peel waste has not been widely published. This research aims to know and study the carcass characteristics of New Zealand White (NZW) crossbred rabbits given FOS (Fructooligosaccharide) from Ambon Banana Peel. The material used in this study were 42 New Zealand White crossbred rabbits 2 months old with 3 replications with 7 treatments, the percentage of FOS was $0 \%, 2.5 \%, 5 \%$, $7.5 \%, 10 \%, 12.5 \%$, and $15 \%$, which is given through drinking water after 2 weeks of maintenance for 7 consecutive days at $08.00 \mathrm{am}$. The conclusion of this study that the provision of FOS (Fructooligosaccharide) from banana peel isolation had a significant effect on the carcass characteristics of New Zealand White crossbred rabbits $(\mathrm{P}<0.05)$ on carcass weight, meat weight, bone percentage, and had a very significant effect $(\mathrm{P}<0.01)$ on carcass percentage.
\end{abstract}

\section{Introduction}

Banana peels have benefits to be used as animal feed, and the benefits will be even better through extraction and isolation that can produce FOS (Fructooligosaccharide)the isolation method of FOS has obtained IPR with IDP000063596 number (Kaffi et al., 2014). FOS is an alternative solution to control colibacillosis as an antimicrobial substance that can eliminate pathogenic bacteria in the digestive tract and stimulate the immune system (immunostimulants). The fructans contained in FOS produced by hydrolysis of chicory plant inulin have been widely reported, but the production of

FOS from banana peel waste has not been widely published. The FOS study of banana peels is the optimization of local feed ingredients based on agricultural waste in livestock development in Indonesia. In the globalization era Sustainable Development Goals (SDGs), need more efforts must be taken the quality and quantity of animal protein. It is difficult to achieve meat quantity and quality considering the current economic conditions, so this can be done by diversifying the supply of animal protein.

One alternative to meet the needs for meat/animal protein is from rabbits because they are prolific livestock that produces good quality and quantity of meat. Therefore, its maintenance needs attention, 
because the mortality of livestock is very high so that the use of FOS prebiotics from banana peels can increase the intestinal microflora and immunity of rabbits, which as a result is expected to increase growth and better meat quantity and quality Many advantages are obtained from consuming rabbit meat, namely high protein content and low cholesterol, so that rabbit meat can be promoted as healthy meat, besides that the skin and feces still have economic value [7]. Until now, its development as a meat provider is still facing many obstacles because the meat from this livestock has not been popular and accepted by some people, so it is difficult to market it, but currently, rabbit livestock as a source of meat livestock has started to become popular in the community. This study aims to see FOS which has the ability as a prebiotic to carcass quality in the form of cut weight, carcass weight, carcass percentage, and bone percentage.

\section{MATERIALS AND METHODS}

The equipment used is an individual rabbit cage measuring $50 \mathrm{~cm}$ long, $40 \mathrm{~cm}$ wide, and $35 \mathrm{~cm}$ high, complete with 50 cages for eating and drinking, triple beam balance, knife, tray, $\mathrm{pH}$ meter. The materials used were FOS isolation results from the best banana peel stage I (green ambon banana peel), male breed NZW rabbits 2 months old, and commercial rabbit feed obtained from BPPT Ciawi Bogor, West Java.

The research was conducted in the rabbit cage of Lampung State Polytechnic. 50 male New Zealand White (NZW) hybrid male rabbits were randomly placed in individual cages. The treatment for the duration of FOS administration was carried out after a maintenance adaptation period for 2 weeks through drinking water in the morning at $08.00 \mathrm{WIB}$ with the following treatment:

- giving FOS of day $0(\mathrm{P} 0)$

- giving FOS of days $7^{\text {th }}(\mathrm{P} 1)$

- giving FOS of days $14^{\text {th }}(\mathrm{P} 2)$

- giving FOS of days $21^{\text {th }}(\mathrm{P} 3)$

- giving FOS of days $28^{\text {th }}(\mathrm{P} 4)$

- giving FOS of days $35^{\text {th }}$ (P5)

The rations given are the same, namely commercial rabbit rations from BPPT Ciawi Bogor, West Java, which are given ad libitum, as well as drinking water in the morning and evening. The variables observed in this stage were the production performance of carcass weight and weight of carcass components).

a. Cut Weight (grams), Cutting weight is the body weight before slaughter for after 6-10 hours.

b. Carcass weight (grams), measured by weighing the carcass which only consists of meat, fat, and bone tissue, after being carried out at $6^{\circ} \mathrm{C}$ for 22-24 hours [13].

c. Bone weight was obtained by weighing each component of the carcass after separating the meat, fat, and bone using a scalpel (scalpel).

d. Percentage of Carcass, Dressing Percentage or percentage of the carcass is between carcass weight and live weight when slaughtered multiplied by $100 \%$, or can be simplified as follows [12]:

$$
\% \text { Carcass }=\text { carcass weight } \times 100 \% / \text { live weight }
$$

\section{Results and Discussion}

Cutting weight $(\mathrm{g})$, carcass weight $(\mathrm{g})$, bone weight $(\mathrm{g})$ in this study were significantly different at the $5 \%$ level $(\mathrm{P}<0.01)$, and very significantly different from the carcass percentage at the $1 \%$ level $(\mathrm{P}<0$, 01). as shown in Table 1. Cut weight is the bodyweight of the rabbit when it is being cut. Factors that affect the weight of a rabbit slaughtered are age, type, and feed used. Young rabbits will produce a lower slaughter weight compared to adult rabbits. [7] States that growth can occur due to an increase in the number and size of body cells, this process occurs in line with the age and condition of the 
livestock. This result is in accordance with the research of [6] which used 4 types of rabbits (California, Chinchilla, New Zealand aged 80 days and NZW age 90 days) at the same average slaughter weight

(1900-2000 g) and produced carcass weights (1100 - $1180 \mathrm{~g})$.

Table 1. Results of Research on the Effect of Treatment on Cut Weight (g), Carcass Weight (g), Percentage of Carcass (\%), Weight Bone (g), meat weight (g) in New Zealand White Male Rabbits.

\begin{tabular}{llcccccc}
\hline No & \multicolumn{1}{c}{ Parameter } & \multicolumn{5}{c}{ Treatments } \\
\cline { 3 - 7 } & & P0 & P1 & P2 & P3 & P4 & P5 \\
\hline 1 & Cut Weight (g) & $1439,2^{\mathrm{a}}$ & $1858,6^{\mathrm{b}}$ & $2087,6^{\mathrm{c}}$ & $2307,0^{\mathrm{d}}$ & $2392,1^{\mathrm{d}}$ & $2376.4^{\mathrm{d}}$ \\
2 & Carcass Weight (g) & $713,2^{\mathrm{a}}$ & $946,8^{\mathrm{b}}$ & $1086.1^{\mathrm{c}}$ & $1205,6^{\mathrm{d}}$ & $1314,1^{\mathrm{d}}$ & $1356,3^{\mathrm{d}}$ \\
3 & $\begin{array}{l}\text { Percentage of carcass } \\
(\%)\end{array}$ & $49,6^{\mathrm{a}}$ & $50,9^{\mathrm{b}}$ & $52,0^{\mathrm{b}}$ & $52,3^{\mathrm{b}}$ & $54.1^{\mathrm{b}}$ & $55.3^{\mathrm{b}}$ \\
4 & Weight Bone (g) & $251,4^{\mathrm{a}}$ & $250,4^{\mathrm{a}}$ & $251,5^{\mathrm{a}}$ & $253,3^{\mathrm{a}}$ & $253,6^{\mathrm{a}}$ & $252.4^{\mathrm{a}}$ \\
\hline
\end{tabular}

Note:

$\mathrm{a}, \mathrm{b}, \mathrm{c}, \mathrm{d}=$ values followed by unequal letters in the column indicate significantly different $(\mathrm{P}<0.01)$

The long trend test for using FOS using orthogonal polynomials is known that the treatment has a significant effect $(\mathrm{P}<0.01)$ following the equation $\mathrm{Y}=0.8111 \mathrm{X} 2+8.082 \mathrm{X}+1454.4$, as shown in Figure 1.

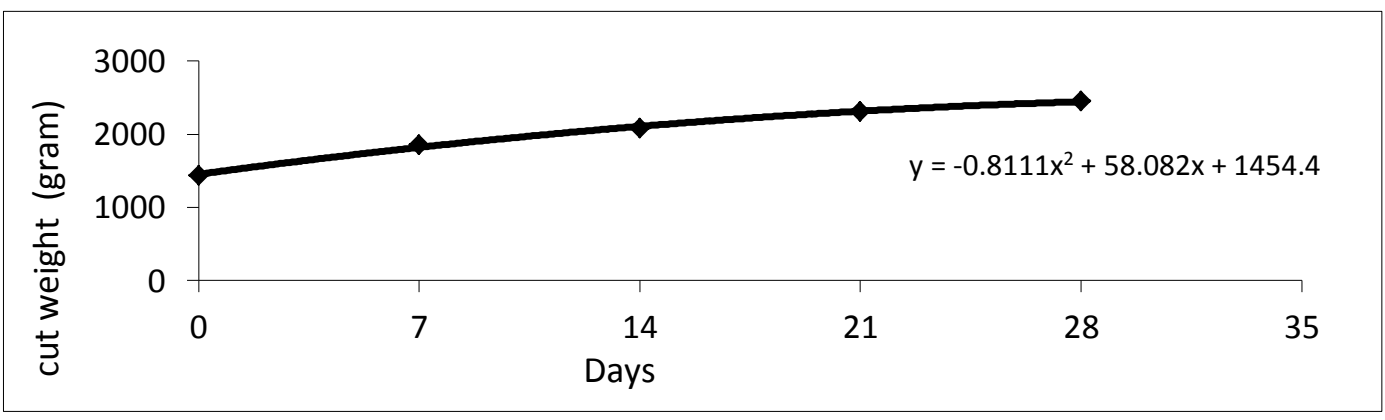

Figure 1. Cut Weight (g) of NZW Treatments of FOS (Fructooligosaccharide) From Ambon Banana Peels

The optimum point of slaughter weight for NZW rabbits on the 35th day is $2494.2 \mathrm{~g}$ (Fig.1), and the coefficient of determination is $99 \%$, which means that the percentage effect of the length of time using FOS on the cutting weight is $99 \%$. Carcass weight and carcass percentage are affected by cut weight. Metzger et al, (2003). Carcass weight, namely the weight after the rabbit is cut minus the blood, head, skin, liver, tail, digestive tract along with its contents, and the contents of the chest cavity, except the kidneys (g) according to [11]. The largest carcass weight was obtained in treatment P4, namely $1414.4 \mathrm{~g}$, and the lowest in treatment P0 (without giving FOS), namely $713.2 \mathrm{~g}$. While the average carcass weight in this study was $1078.4 \mathrm{~g}$. The carcass weight obtained is higher than the research of [1], namely $975.5 \mathrm{~g}$ in the treatment of adding corn oil to the feed. The results showed that the higher the cut weight, the higher the carcass weight and vice versa. Carcass production, which is reflected in meat, fatty, and rabbit repetition, seems to be very much influenced by the weight of the cut. [3] stated that the higher the cutting weight, the higher the carcass weight, and vice versa. [5] State that the carcass components consist of meat, bones, and fat. The trend of the treatment response was 
carried out by orthogonal polynomial test, it was found that the treatment had a linear effect at the real level of $1 \%(\mathrm{P}<0.01)$, following the equation $\mathrm{Y}=20.26 \mathrm{X}+797.6$ as shown in Figure 2 .

Rabbits that have a greater live weight can produce a large percentage of the carcass as well [14] added that along with the increase in live weight, feed consumption also increases. Rabbits that consume more feed tend to accumulate more protein in response to growth and increase in carcass weight. Carcass and carcass percentages are highly dependent on breed, environment, live weight, and nutrients in feed. The percentage of the carcass has a positive relationship with the energy content in the ratio. A slight increase in body size can lead to a proportional increase in the bodyweight of an animal [11]. The results of calculating the percentage of the carcass are in line with the results of measurements of cut weight (live weight) and carcass weight because the percentage of the carcass is the ratio between carcass weight and live weight when cut (minus the contents of the digestive tract and urine) times $100 \%$ [12].

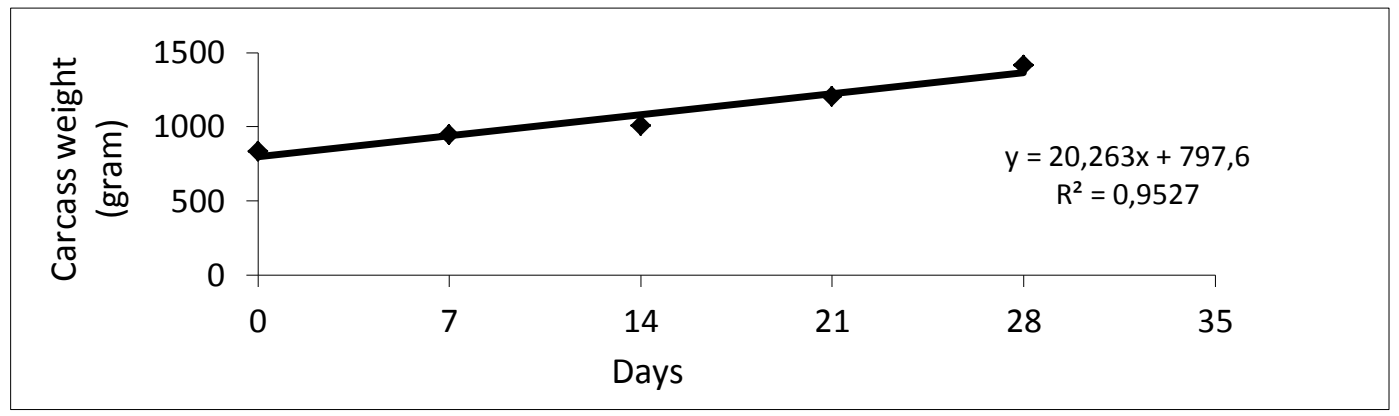

Figure 2. Carcass Weight (g) of Treatment of FOS (Fructooligosaccharide) from Ambon Banana Peels.

Research on the effect of treatment on the percentage of the carcass, the highest was in treatment R4, namely $57.6 \%$, and the lowest was in treatment R0 (without the addition of FOS), namely $49.6 \%$. This carcass percentage is still higher than the results of research by [10] which obtained an average carcass percentage of 55\% in NZW rabbits. [5] Reported carcass production of New Zealand White (NZW) rabbit carcasses, local, NZW-local, and Chinchilla-local crosses, respectively, of 45.8; 42.6; 48.9 , and $46.7 \%$. Carcass production, which is reflected in meat, fat, and rabbit repetition, seems to be very much influenced by the weight of the cut. The weight of carcass components includes weight of meat,

fat, and bone (g), the weight of commercial cuts, foreleg, rack, loin, and hindleg [2].

\section{Conclusions}

Ambon banana peel contains Fructooligosaccharide (FOS) which has a strong potential as a prebiotic, as evidenced by its ability to improve rabbit production performance by increasing carcass quality, including slaughter weight, carcass weight, carcass percentage, but does not have an effect on the bone weight of New Zealand White crossbreed rabbits.

\section{References}

[1] Agustin Pratiwi, Supadmo, Andriyani Astuti, dan Panjono. 2017. Growth Performance and Carcass Production of Rex Rabbits Feed With Corn Oil Supplementation. Bulletin of Animal Science. Vol 41(2):119-125.

[2] Blasco, A., J. Ouhayoun and G. Masoero. 1992. Study of rabbit meat and carcass:Criteris and terminology. Journal Appl. Rabbit Res. 15: 775 -786.

[3] Brahmantiyo B, Raharjo YC,Martojo H,Mansjoer SS. 2010. Performa produksi rex, satin dan persilangannya.JITV.15(2):131-137. 
[4] Diwyanto, K. Sunarlim dan P. Sitorus. 1998. Pengaruh persilangan terhadap nilai karkas dan preferensi daging kelinci panggang. Jurnal Ilmu Peternakan. 1(10): 427 - 430.

[5] Haryoko. I. Dan Titik Warsiti. 2008. Pengaruh Jenis Kelamin dan Bobot Terhadap Karateristik Fisik Karkas Peranakan New Zealand White. Journal. Animal Production. 2(10): 85 - 89.

[6] Hernandez, J. A., M. S. Rubio Lozano R. D. and Carregai. 2001. Effect of Breed and Sex On Rabbit carcass Yield and Meat Quality. J. Meat Science Labolatory,Facultad de Medicina Veterinaria Zootecnia. Universid Nacional Autonoma de Mexico, Mexico.

[7] Husmy Yurmiati. 2006. Hubumgan Berat Potong dengan Berat, Tebal Pelt Kelinci. Jurnal Ilmu Ternak. 1 (6) : $48-52$.

[8] Kaffi S.S.,Zulfahmi dan Hertini Rani, 2014. HAKI Metode Proses Isolasi FOS dari Kulit Pisang no POO201406459. tertanggal 23 Oktober 2014. Departemen Hukum dan Ham Republik Indonesia. Jakarta.

[9] Metzger,S.,K.Kustos,Z.Szendro,A.Szabo,C.Eiben,and I.Nagy.2003.The Effect of Housing System on Carcass Traits and Meat Quality of Rabbit. Journal World Rabbit Sci. 11: 1-11.

[10] Prata, M.B.and Mussato.2010. Fructooligosaccharide production by Penicillium expansum.Journal Biotechnol Lett(32):837-840.

[11] Rao,.D.R,G.R.Sunki,W.H.Johnson,C.P.Chen.1978.Effect ofweaning and slaughter age on rabbit meat productions II.carcass, quality and composition. Journal Animal Sci 5:578-582.

[12] Santoso, U dan Sutarno. 2010. Bobot Potong Dan Karkas Kelici New Zealand White Jantan Setelah Pemberian Ransum Kacang Koro (Mucuna prurien var. utilis). Jurnal. Bioteknologi. 7(1):19-26.

[13] Soeparno. 2009. Ilmu dan Teknologi Daging. Cetakan V. Gadjah Mada University Press.Yogyakarta.

[14] 2011. Tehnologi Pengawasan Daging. Fakultas Teknologi Pertanian Bogor, Bogor. 